This item was submitted to Loughborough's Research Repository by the author.

Items in Figshare are protected by copyright, with all rights reserved, unless otherwise indicated.

\title{
Media coverage of women athletes during the Olympic Games
}

PLEASE CITE THE PUBLISHED VERSION

https://www.routledge.com/Routledge-Handbook-of-the-Business-of-Womens-Sport-1st-Edition/LoughGeurin/p/book/9780203702635

\section{PUBLISHER}

Routledge

VERSION

AM (Accepted Manuscript)

\section{PUBLISHER STATEMENT}

This is an Accepted Manuscript of a book chapter published by Routledge in Routledge Handbook of the Business of Women's Sport on 21 May 2019, available online: http://www.routledge.com/9780203702635.

\section{LICENCE}

CC BY-NC-ND 4.0

\section{REPOSITORY RECORD}

Geurin, Andrea. 2019. "Media Coverage of Women Athletes During the Olympic Games". figshare. https://hdl.handle.net/2134/11912472.v1. 


\title{
Media Coverage of Women Athletes During the Olympic Games
}

\author{
Andrea N. Geurin, Ph.D. \\ New York University
}

\section{Introduction}

Women athletes have competed in the Olympic Games since 1900, when 22 women (2.2\% of all competitors) participated in tennis, sailing, croquet, equestrian, and golf at the Paris Olympics. These numbers steadily climbed over time, and by 2016 , women made up $45 \%$ of all competitors at the Rio de Janeiro Summer Olympic Games (Crockett, 2016). Additionally, at the 2018 Winter Olympics in PyeongChang, South Korea, 43\% of all athletes were women, a record for the Winter Olympics (Taylor, 2018). Despite the increase in women athletes competing in the Games, male athletes have historically received more media coverage during the Games (e.g., Billings, Angelini, \& Duke, 2010; MacArthur, Angelini, Smith, \& Billings, 2017), and indeed male athletes have consistently been shown to receive far more media coverage than their female counterparts in general (e.g., Bishop, 2003; Eagleman, Pedersen, \& Wharton, 2009; Fink \& Kensicki, 2002; Greer, Hardin, \& Homan, 2009; King, 2007).

As one of the only major international multisport events to feature both men and women competitors, the Olympic Games are unique in that they provide an opportunity for more equitable media coverage between men and women athletes. For the vast majority of sport fans and consumers, the Olympic Games are consumed via media rather than in-person, which underscores the importance of equitable coverage during this event to present sport consumers with an accurate picture of the Games (Billings, 2007). According to Eagleman, Burch, and Vooris (2014), providing equitable coverage can result in accurate historical records being kept and preserved. Additionally, when news outlets consistently provide equitable coverage of male and female athletes, shifts in societal biases and stereotypes can occur. For example, when coverage highlights the accomplishments and performances of both men and women athletes, potential outcomes include a greater societal respect for women's sport and women athletes, greater participation by women in sport, increased media coverage for women athletes in nonOlympic years, and "ultimately greater acceptance of and respect for women in all areas of society" (Eagleman, Burch, \& Vooris, 2014, p. 465).

This chapter seeks to present an historical overview of both the amount and quality of coverage devoted to women athletes during the Olympic Games, while also discussing the emergence of new media and the potential benefits Internet-based media coverage holds for women athletes, and the power that social media affords women athletes in terms of promoting their careers and seeking commercial opportunities. The chapter concludes with a profile of Olympic gold medalwinning gymnast, Nastia Liukin, who is now a member of U.S.-based broadcaster NBC's Olympic broadcast team and who founded a company focused on empowering young female athletes via the use of a mobile app.

\section{Olympic Media Coverage Devoted to Women}

Amount of Coverage 
Myriad studies have examined the amount of coverage devoted to men and women during the Olympic Games. Time and time again, these studies have shown discrepancies in the amount of coverage, with men often receiving significantly more than the women. For example, several scholars have examined coverage in terms of clock time devoted to male and female athletes. As far back as the 1992 Barcelona Summer Olympic Games, Higgs and Weiller (1994) found that U.S. broadcaster NBC devoted more of its coverage to men than women. The focus on NBC's coverage has continued, with Billings et al. (2008) finding that men received $60 \%$ of the clock time during NBC's television coverage of the 2006 Torino Winter Olympics, and men also constituted the majority $(60 \%)$ of the top 20 most mentioned athletes. Two years later, Billings et al. (2010) examined NBC's television coverage of the 2008 Beijing Summer Olympics, finding a greater disparity in clock time between men and women than at the previous Summer Games in Athens, with men receiving significantly more coverage. The focus on NBC is warranted, as the network has had exclusive rights to broadcast the Games in the U.S. since 1992, and extended its deal with the International Olympic Committee in 2014, paying an astronomical $\$ 7.75$ billion for rights to broadcast the Games from 2022 to 2032 (Sandomir, 2014). Thus, it is the only televised coverage available to Olympic consumers in the United States and its coverage paints a picture of the Games for those who cannot attend the three-week long event in person. The sports and athletes shown on NBC's broadcasts shape U.S. media consumers' perceptions of the event and which sports and athletes are most important.

The issue of inequitable coverage is not limited to television, as many scholars have found the same to be true of print coverage as well. For example, Zurn, Lopiano, and Snyder (2006) examined the New York Times' coverage of the 2006 Winter Olympics and found that nearly $62 \%$ of the outlet's coverage focused on men's sport, while just $38 \%$ focused on women. The percentage of photos featuring men was even higher at 64\%, to women's 36\%. Similarly, Smith and Wrynn (2010) examined U.S. newspaper and website coverage of the 2010 Winter Olympics in Vancouver, Canada, and found that all outlets examined (New York Times, USA Today, Sacramento Bee, NBC Olympic website, ESPN website) afforded far greater coverage to men than women, with men receiving a combined total of $62.4 \%$ of coverage to women's $37.6 \%$. The men also received more favorable article placement and more photographs than women. Arguing for greater coverage for women, the authors wrote that media coverage "can play a significant role in exposing girls and women to a variety of sport participation opportunities, as well as shaping our culture's ideas of a wide range of acceptable gender roles worthy of recognition and celebration for both females and males" (p. 41).

While much attention has been focused on U.S.-based news outlets and their coverage of the Olympic Games, it is important to also understand coverage trends in countries outside of the U.S. One such study was Eagleman, Clavio, and Kwak's (2011) comparison of online news coverage between a U.S.-based online news outlet (USA Today) and a Chinese-based online news outlet (People's Daily). The researchers found coverage from both countries to favor male athletes, but the disparity between the amount of coverage of men and women was much higher for the U.S.-based outlet. Another study focused on China's media coverage examined Chinese Central Television's (CCTV) coverage of gymnastics at the 2016 Olympic Games, hypothesizing that women would receive more coverage (Xu, Billings, \& Fan, 2018). To the authors' surprise, however, the men competing in gymnastics received more clock time, more total name mentions 
in the broadcasts, and 13 of the top 20 most-mentioned athletes were men. Hedenborg (2013) examined coverage of the 2012 London Olympics from a Swedish media lens, and unsurprisingly found that men received greater coverage from both a daily newspaper and a tabloid newspaper. She argued that media coverage plays an important role in shaping society's views on who is and is not considered a "real sportsman or sportswoman" (p. 800), highlighting the need for greater coverage of women athletes in order to legitimize them in the minds of society.

Another study focused on Canada's television coverage of the 2014 Sochi Winter Olympics on the Canadian Broadcasting Corporation's (CBC) broadcasts, revealed that men received over $60 \%$ of airtime compared to women's nearly $40 \%$, men received more mentions, and men made up $65 \%$ of the top 20 most-mentioned athletes list (MacArthur, Angelini, Smith, \& Billings, 2017). Still, the authors noted that outside of Olympic competition, women received only $1.7 \%$ to $3.1 \%$ of all television sports coverage in Canada, suggesting the $40 \%$ received during the Sochi Olympics was a marked improvement from non-Olympic coverage. This sentiment was echoed in Packer et al.'s (2014) examination of British media coverage of women's sport in the five months leading up to and the five months following the 2012 London Olympic Games. The authors found no evidence that Great Britain's hosting of the 2012 Games led to improved coverage of women's sport, with women receiving just $4.5 \%$ of coverage prior to the Games and an even lower $2.9 \%$ of coverage after the Games. Packer et al. (2014) also found that for every photo of a woman athlete featured in British newspapers, there were 25 photos of men athletes. The authors cautioned of potential negative consequences of this dismal coverage, such as lower sport participation rates for women and girls in Great Britain, which could lead to adverse health implications.

Despite these discouraging findings relating to the amount of coverage devoted to women athletes during the Olympic Games, the proportion of women athletes competing in the Olympic Games has steadily risen over time. In 2016, not only was the percentage of women the highest ever at $45 \%$ of all competitors, but women were touted as being the stars of the Games in many media accounts. U.S.-based news outlet NPR dubbed the American women as "the biggest winners" at the Rio Games (Myre, 2016, para. 1), and the New York Times reported that in 29 of the nations competing in the Games, women won more medals for their country than the men, including traditional powerhouse countries such as the United States, China, and Russia (Lai \& Lee, 2016). While a great deal of the research presented to this point in the chapter shows inequitable coverage for women during the Olympics, a more optimistic body of research has begun to emerge, which reveals improvements in equity of coverage. One such example is Eagleman, Burch, and Vooris's (2014) comparison of online media coverage of the 2012 Olympic Games from outlets in Australia, Brazil, China, Great Britain, Kenya, and the United States, which found that all six countries afforded a greater percentage of coverage to male athletes than female, but the difference was not statistically significant when tested against the independent standard of the number of participants from each gender. In terms of article placement on the news website, only Kenya's Daily Nation afforded significantly better placement to male athletes. This finding was one of the first of its kind, in which Olympic media coverage was found to be equitable between men and women. The authors concluded that the Internet may allow for more equitable coverage than traditional media in terms of the amount of 
coverage, and that "the relative absence of time and space restraints on news websites helps to facilitate more equitable and representative coverage" (p. 466).

Lending credence to the notion that the Internet may represent a step forward in the direction of gender equity, Burch, Eagleman, and Pedersen (2012) found that while men received more coverage on the NBC Olympics website, Yahoo! Sports website, and USA Today website during the 2010 Vancouver Winter Olympics, the amount of coverage was not statistically significant when compared to the independent standard of the number of athletes of each gender participating in the Games. Burch et al. (2012) noted that this was a departure from traditional media trends, as previous research showed statistically significant differences in the amount of coverage devoted to men and women during the 2000, 2002, 2004, and 2006 Olympic Games. Finally, Billings, Angelini, MacArthur, Bissell, and Smith (2014) found that in 2012, NBC devoted more coverage to women athletes than men in the London Olympic Games. While the work by Eagleman et al. (2014), Burch et al. (2012), and Billings et al. (2014) indicate marked improvements in terms of equitable coverage, more quantitative analyses are necessary, specifically focused on the 2014, 2016, and 2018 Olympics and beyond, in order to understand whether the trend of more equitable coverage continues.

\section{Quality of Coverage}

Along with the amount of coverage afforded to women athletes, the quality of coverage is also very important in terms of equity and shaping societal views of women athletes. Fink (2015) wrote that what was even more disturbing than the lack of coverage afforded to women athletes was "the fact that when female athletes are provided coverage, it is disparagingly different than that afforded to male athletes" (p. 333). Further, Cooky and Antunovic (2018) cautioned scholars to be careful in celebrating greater equity in terms of the amount of coverage afforded to women, stating that "these indicators of progress exist alongside forms of blatant sexism, racism, and discrimination" (p. 946). That is, just because the amount of coverage of male and female athletes during the Olympic Games is reaching a level of equity, the language and portrayals used to describe women athletes still needs improvement.

Research has shown a long history of coverage in which the size and strength of men's bodies is a central focus, and they are often portrayed as being powerful and strong (e.g., Billings, 2003; Billings \& Eastman, 2003), whereas when women receive coverage, it often seeks to diminish their athletic accomplishments by focusing on their attractiveness, femininity, and sexuality (e.g., Bissell \& Duke, 2007; Eastman \& Billings, 1999). In her review of media coverage of women's sport, Fink (2015) identified five common practices employed by the media when reporting on women, which are used so often that they are deeply embedded in our cultural psyche and many consumers do not even notice or question them.

The first practice Fink (2015) identified was a term Messner, Duncan, and Jensen (1993) coined "gender marking". This is the practice of presenting male athletes as the norm, while female athletes are relegated to second-class status. One way in which this is accomplished is through the use of the word "Women" in the title of sporting events such as the FIFA Women's World

Cup. Meanwhile, the men's competition is simply the FIFA World Cup, with no mention of their sex in the title. 
Next, Fink (2015) identified the practice of infantilizing women athletes, a process by which women are often referred to as "girls" or "young ladies". Eagleman, Rodenberg, and Lee (2014) examined this concept in the context of women's Olympic gymnastics, studying language used to describe women gymnasts from the 1984 Olympic Games through the 2008 Olympic Games. They found that over time, less infantilizing language was used by the journalists to describe the female gymnasts, but the coaches and other gymnastics officials routinely used such language in their quotes when speaking about the gymnasts, illustrating the earlier point that these gendered language practices are deeply embedded in our culture. Another method of infantilizing is by referring to women only by their first names, but not doing so when discussing male athletes. Messner et al. (1993) indicated that this serves to diminish the reputations of female athletes. It may also be a method for reinforcing ambivalent attitudes, which is the third practice Fink (2015) identified. According to Eagleman (2015), it is a practice by which the media present information that at first seems positive, but upon further investigation it is actually used to subtly belittle women athletes. An example from Eagleman's (2015) study on newspaper portrayals of male and female gymnasts from the 2012 Olympics was journalists' displeasure with the women gymnasts' frowning and concentration on their faces while performing more difficult skills than had ever been done before. Eagleman (2015) said, "This desire for pleasant facial expressions serves to objectify gymnasts as pretty things meant to bring joy to the audiences and further stereotypes gymnastics as a female appropriate sport" (p. 244).

Along those lines, the fourth practice identified by Fink (2015) was a focus on femininity and heterosexuality. By focusing on the athletes' femininity, sex appeal, and aspects of heterosexuality such as their families, romantic partners, or roles as mothers, these portrayals serve to diminish their athletic accomplishments. Indeed, an examination of NBC's coverage of women athletes in the 2016 Rio Olympic Games revealed that the broadcast network focused on heterosexualizing athletes and highlighting their roles as wives and mothers (Villalon \& WeillerAbels, 2018). In one example from Villalon and Weiller-Abels' study, an NBC announcer referred to a lesbian volleyball player's female partner as her "husband", seeking to heterosexualize the athlete. In another example, an announcer referred to a Hungarian swimmer's husband as 'the guy responsible' for her success, belittling her abilities and suggesting she needed a man to achieve success in her sport.

Finally, Fink (2015) explained that the production techniques used for men's and women's sport are different, and research has shown that this results in women's sport being perceived as less exciting than men's. Fink pointed out several examples of this, including more camera angles/shots used in men's sport, more on-screen graphics in broadcasts of men's sport, camera angles that highlight women's buttocks and chests, and selective gender comparisons in which women are compared only to men who outperform them, but no mention is made of how many men the woman is superior to, such as in marathon coverage where a women's race winner is faster than the vast majority of men participating in the same race. Yet, in most marathon coverage, the women's race winner is only compared to the men's race winner (Kane, 1995).

The results of recent studies focused on quality of coverage, such as those by Villalon and Weiller-Abels (2018), Eagleman (2015), and Eagleman, Rodenberg, and Lee (2014) point to the 
continuation of problematic portrayals of women athletes, which seek to diminish their accomplishments and perpetuate the notion of male dominance in sport.

\section{Opportunities for Women Olympic Athletes via Social Media}

Although it is well documented that both the quantity and quality of mainstream media coverage of women athletes need improvement, several scholars (e.g., Geurin, 2017; Geurin-Eagleman \& Burch, 2016; Lebel \& Danylchuk, 2012) have pointed to social media as a potential equalizer for women athletes, as social media platforms allow the athletes to post news and updates themselves, thus directly promoting their performances and careers without reliance on traditional media. Additionally, social media allows athletes to build their personal brands and craft their desired images in the minds of fans and sport consumers (Arai, Ko, \& Ross, 2014). Social media is thought to be an especially useful tool for Olympic athletes, who often do not benefit from being part of teams/organizations that receive a great deal of social media and traditional media coverage in non-Olympic years (Eagleman, 2013).

Geurin-Eagleman and Burch (2016) examined Olympic athletes' Instagram posts and found that photos of athletes engaged in their sport (e.g., action shots) elicited greater engagement from followers. Despite this, however, women athletes posted more photos of themselves in personal life settings, thus missing an opportunity to establish larger fan followings and elicit greater engagement with their posts. The authors concluded, "The prevalence of personal life photos posted by female athletes reflected the traditional practices of mainstream sports media outlets, which can have implications for these athletes in terms of the followers they attract and the brand image they project" (p. 142). Additionally, the women athletes were found to post more sexually suggestive images of themselves than the men, and the authors cautioned that "athletes should be careful when posting such photos, as they could have long-term consequences on the public's perceptions of the athlete. It is imperative that the types of photos posted align closely with the brand image the athlete wishes to build" (p. 142). Interestingly, Kane and Maxwell (2011) found that sexually suggestive images of women athletes did not elicit more interest in women's sport from neither men nor women, who were more interested in photos displaying athletic competence.

Geurin (2017) sought to build on the content analysis conducted by Geurin-Eagleman and Burch (2016) by speaking directly with women athletes to better understand their perceptions of using social media as a marketing communication tool related to their careers. While the athletes, all of whom were training for the 2016 Summer Olympics, appeared to have goals for their social media use (e.g., sharing their lives, developing connections, sponsorship, and self-promotion), none employed specific strategies to achieve these goals, nor did they attempt to use any measurement mechanisms by which to assess whether their goals were met. Social media offers the potential for helping women athletes build their profile, which could lead to positive outcomes such as larger fan bases, sponsorship/endorsement opportunities, and overall greater recognition for and interest in themselves and their sports. Despite these potential benefits, however, evidence such as that from Geurin's (2017) study points to women athletes underutilizing this tool. This reveals an opportunity for women athletes and those who work with them (e.g., agents, publicists, national governing bodies) to develop specific strategies for their social 
media use to build their personal brands and develop greater recognition for themselves, their achievements, and their sport in the public eye.

Despite the potential benefits social media provides women athletes, especially those in Olympic sports, there are also documented risks associated with social media use that extend beyond posting something that may negatively affect public perception of the athlete. In speaking with women Olympic athletes, Geurin (2017) found that each athlete described receiving unwanted direct private messages from "fans" and followers on social media platforms. These unwanted communications were highly inappropriate and some bordered on the act of stalking. For example, one woman boxing athlete describing the messages she received in the following quote:

I've had a few people tell me that they want to be married to me and they send me inbox messages. One guy told me once that he dreams of me every day and another guy told me once that he knows everything about me. Like he's Googled every last thing about me. And then I've had a few guys send me pictures of their private areas through Facebook messages. I have a very long "block" list of people who cannot contact me (Geurin, 2017, p. 351).

Challenges such as this one, in which some athletes fear for their personal safety, can seek to turn women athletes away from social media, thus denying them of the potential benefits social media affords to them. Given that traditional media still lags in equal and equitable coverage of women athletes and women's sport, it is disheartening that some women athletes are also unable to utilize social media as a marketing communication tool due to "a combination of hegemonic masculinity, sexism, and harassment" (Geurin, 2017, p. 354), which "highlights a larger societal problem with regard to women's equality" (p. 354).

Still, some athletes have recently begun to use social media as a means for speaking out about injustices, harassment, and abuse. In October 2017, the "\#MeToo Movement" took over social media in all areas of life - not just sport, with over 12 million Facebook posts featuring the hashtag within 24 hours of actress Alyssa Milano encouraging people, especially women, to share their stories of sexual assault and harassment (Smartt, 2017). \#MeToo spurred a movement in which women in all sectors of society began speaking out about their experiences, and it seemed to give women an unprecedented confidence, platform, and voice to speak out about gender-related injustices, build awareness for these issues, and demand change. As a result, some Olympic athletes and their fans/followers began using social media as a way to draw attention to situations that may have never reached public consciousness otherwise, and have been able to ultimately influence positive change in some instances.

One high-profile example came in October 2018 when five-time Olympic medalist in gymnastics, Simone Biles, posted a tweet that was critical of Mary Bono, the newly-appointed interim CEO of USA Gymnastics, the sport's national governing body. Prior to Bono's appointment, USA Gymnastics had been roiled by a sexual abuse scandal in which the national team doctor, Larry Nassar, was found to have abused hundreds of gymnasts, including several national team members, in the 20 years he was in his position. When Bono took over for the recently-resigned and widely criticized CEO Kerry Perry, Biles took to Twitter to retweet a post by Bono that was critical of Nike-sponsored athlete Colin Kaepernick, along with a photo showing Bono blacking-out the Nike logo on her shoes with a Sharpie marker. Biles wrote, 
“*mouth drop* don't worry, it's not like we needed a smarter USA gymnastics president or any sponsors or anything" (Hill, 2018, para. 15). Biles' Olympic teammate from 2016, Aly Raisman, a five-time medalist herself, also tweeted about Bono, writing, "My teammates \& I reported Nassar's abuse to USAG in 2015. We now know USOC \& lawyers at Faegre Baker Daniels (Mary Bono's firm) were also told then, yet Nassar continued to abuse children for 13 months!? Why hire someone associated with the firm that helped cover up our abuse?" (Hill, 2018, para. 6). Just four days later, only five days into her term as interim CEO, Bono resigned from the position due to the pressure from the athletes and their fans, thousands of whom "liked", "retweeted", responded to the tweets, and tweeted their disapproval directly to Bono's account (Adams, 2018). The support shown by fans and followers in this example helps to highlight the power of what Cooky and Antunovic (2018) described as "“call out' culture" (p. 947), which they argued "challenges conventional forms of male-dominance and masculine hegemony in sports media" (p. 947). Women's newfound empowerment stemming from the \#MeToo movement is only just beginning to be felt in society, and is a movement ripe for women athletes to use to highlight the inequalities and injustices they have faced for decades in sport.

\section{Conclusion}

The lack of coverage for women athletes is well documented, and while women athletes receive much more equitable coverage during the Olympic Games, the need for greater coverage in nonOlympic years remains. Perhaps more important than the amount of coverage devoted to women, however, is the need for more equitable coverage in terms of quality. As discussed in this chapter, several antiquated practices persist in sports media with regard to the portrayals of women athletes and the language used to describe them. In order for women's sport to reach a level where it is legitimized in society, the language used to describe women athletes and women's sport must be free of the five gendered practices identified by Fink (2015).

Social media use offers women athletes, especially those in Olympic sport, the opportunity to build their own brand and desired public image, but in order to take advantage of social media's opportunities, women athletes must develop social media goals, strategies to achieve those goals, and measurement techniques to understand whether they are truly reaching their goals. Unfortunately, the harassment felt by some women athletes on social media by their male "fans" may prove to be a deterrent to the otherwise equalizing opportunity that social media use provides. This points to a larger, problematic societal belief in male hegemony, or the idea that men have the power to dominate others (namely, women) and can therefore treat them in ways that are disrespectful and harassing in nature. Women's empowerment movements such as \#MeToo will help women athletes to conquer some of these situations, but it is obvious that a larger shift in our societal mindset when it comes to views on men and women is necessary for this issue to truly improve. One interesting mechanism by which to bring women together for greater unity and empowerment may be through the use of technology, such as mobile device apps that connect women athletes to each other for support and friendship. One such example is provided in the following leader profile on five-time Olympic medalist Nastia Liukin.

\section{Leader Profile: Nastia Liukin}

$<$ INSERT PHOTO 1 HERE $>$ 
Born in Moscow, Russia, to a father who was an Olympic champion in men's gymnastics and a mother who was a World Champion in rhythmic gymnastics, Anastasia "Nastia" Liukin grew up learning the sport of gymnastics in her parents' gym in Plano, Texas, where they moved when she was two and a half years old. By age 18 she was a five-time Olympic medalist and just the third American woman to win the coveted Olympic All-Around gold medal at the 2008 Beijing Olympic Games. The same year, she was named the Women's Sports Foundation's "Individual Sportswoman of the Year", USA Gymnastics' "Sportswoman of the Year", and won "Best Female Athlete" at the 2009 ESPY Awards.

While completing her bachelor's degree in Sports Management at New York University, Liukin entered the world of sports broadcasting, joining the NBC Sports Group as an analyst during the 2012 Summer Olympics in London, then serving as a special correspondent for NBC during the 2014 Sochi Winter Olympics in Russia. She has since become a regular member of the NBC Sports broadcast team for national, World, and Olympic gymnastics competitions as a gymnastics analyst, providing a unique perspective as a former athlete and as someone who has close ties to many of the athletes she covers, leading to the sharing of interesting facts and insights about the gymnasts that were not covered before her tenure at NBC.

Along with her role as a gymnastics analyst for NBC, Liukin founded an organization in 2016 called "Grander", which is "an inspirational Mobile App for motivated gymnasts to be mentored by their biggest role models. They can connect and communicate with them, learn valuable lessons for their sport and receive exclusive content" (Duffy, 2018, para. 5). By connecting with young girls and women primarily through a mobile app, Liukin is meeting these athletes where they most often consume sport and interact with their peers. Her goal for the app is to empower young women by assisting them in acquiring the tools they need to succeed in all aspects of their lives: athletically, personally, and professionally.

In addition to the app, Liukin has hosted several Grander Summits in cities around the U.S., where she and other former world-caliber gymnasts connect with young female athletes. Liukin said, "Even when I was competing, there was always the importance of having a mentor in my life. Regardless of what you want to be, whatever your dreams or goals are, to get connected, to gain knowledge and inspiration from the people you look up to is so important" (Gardner, 2018, para. 2). While the Grander app is currently limited to a community for gymnasts, Liukin hopes to expand it to additional sports in the future so that other athletes can also benefit from the mentorship connections it establishes for young athletes. 


\section{References}

Adams, D. (2018, October 17). Here's everything we know about Mary Bono and her abrupt departure from USA Gymnastics. Indianapolis Star. Retrieved from https://www.indystar.com/story/news/2018/10/17/mary-bono-resigns-usa-gymnasticssonny-bono-nike-tweet-simone-biles-everything-we-know/1669213002/

Arai, A., Ko, Y.J., \& Ross, S. (2014). Branding athletes: Exploration and conceptualization of athlete brand image. Sport Management Review, 17, 97-106.

doi:10.1016/j.smr.2013.04.003

Billings, A.C. (2003). Dueling genders: Announcer bias in the 1999 U.S. Open tennis tournament. In R.S. Brown \& D. O’Roarke (Eds.), Topics in Sport Communication. Westport, CT: Praeger.

Billings, A.C. (2007). From diving boards to pole vaults: Gendered athlete portrayals in the "big four" sports at the 2004 Athens Summer Olympics. Southern Communication Journal, 72(4), 329-344.

Billings, A.C., Angelini, J.R., \& Duke, A.H. (2010). Gendered profiles of Olympic history: Sportscaster dialogue in the 2008 Beijing Olympics. Journal of Broadcasting \& Electronic Media, 54(1), 9-23. https://doi.org/10.1080/08838150903550352

Billings, A.C., Angelini, J.R., MacArthur, P.J., Bissell, K., \& Smith, L.R. (2014). (Re)calling London: The gender frame agenda within NBC's primetime broadcast of the 2012 Olympiad. Journalism \& Mass Communication Quarterly, 91(1), 38-58. https://doi.org/10.1177/1077699013514416

Billings, A.C., Brown, C.L., Crout, J.H., McKenna, K.E., Rice, B.A., Timanus, M.E., \& Ziegler, J. (2008). The games through the NBC lens: Gender, ethnic, and national equity in the 2006 Torino winter Olympics. Journal of Broadcasting \& Electronic Media, 52(2), 215230. https://doi.org/10.1080/08838150801992003

Billings, A.C., \& Eastman, S.T. (2003). Framing identities: Gender, ethnic, and national parity in network announcing of the 2002 Winter Olympics. Journal of Communication, 53(4), 569-586.

Bishop, R. (2003). Feature coverage of women's sports in Sports Illustrated. Journal of Sport \& Social Issues, 27(2), 184-194.

Bissell, K.L., \& Duke, A.M. (2007). Bump, set, and spike: An analysis of commentary and camera angles of Women's Beach Volleyball during the 2004 Summer Olympics. Journal of Promotion Management, 13(1/2), 35-53. 
Burch, L.M., Eagleman, A.N., \& Pedersen, P.M. (2012). New media coverage of gender in the 2010 Winter Olympics: An examination of online media content. International Journal of Sport Management, 13, 143-159.

Cooky, C., \& Antunovic, D. (2018). The visibility of feminism in the Olympic Games: Narratives of progress and narratives of failure in sports journalism. Feminist Media Studies, 18(5), 945-948. https://doi.org/10.1080/14680777.2018.1498100

Crockett, Z. (2016, August 5). More women will compete in Rio 2016 than in any other Olympics. Vox. Retrieved from https:/www.vox.com/2016/8/5/12386612/rio-olympics2016-women

Duffy, P. (2018, January 31). Industry Insider: Grander. Inside Gymnastics Magazine. Retrieved from https://www.insidegymnastics.com/news-features/industry-insider-grander/

Eagleman, A.N. (2013). Acceptance, motivations, and usage of social media as a marketing communications tool amongst employees of sport national governing bodies. Sport Management Review, 16(4), 488-497. http://dx.doi.org/10.1016/j.smr.2013.03.004

Eagleman, A.N. (2015). Constructing gender differences: Newspaper portrayals of male and female gymnasts at the 2012 Olympic Games. Sport in Society, 18(2), 234-247. doi:10.1080/17430437.2013.854509

Eagleman, A.N., Burch, L.M., \& Vooris, R. (2014). A unified version of London 2012: Newmedia coverage of gender, nationality, and sport for Olympics consumers in six countries. Journal of Sport Management, 28(4), 457-470. http://dx.doi.org/10.1123/jsm.2013-0151

Eagleman, A.N., Pedersen, P.M., \& Wharton, R. (2009). Coverage by gender in ESPN The Magazine: An examination of articles and photographs. International Journal of Sport Management, 10(2), 226-242.

Eagleman, A.N., Rodenberg, R.M., \& Lee, S. (2014). From "hollow-eyed pixies" to "team of adults": Media portrayals of Olympic women's gymnastics before and after an increased minimum age policy. Qualitative Research in Sport, Exercise and Health, 6(3), 401-421. doi: 10.1080/2159676X.2013.877961

Eastman, S.T., \& Billings, A.C. (1999). Gender parity in the Olympics: Hyping women athletes, favoring men athletes. Journal of Sport \& Social Issues, 23, 140-170.

Fink, J.S. (2015). Female athletes, women's sport, and the sport media commercial complex: Have we really "come a long way, baby"? Sport Management Review, 18(3), 331-342. https://doi.org/10.1016/j.smr.2014.05.001 
Fink, J.S., \& Kensicki, L.J. (2002). An imperceptible difference: Visual and textual constructions of femininity in Sports Illustrated and Sports Illustrated for Women. Mass Communication \& Society, 5, 317-339.

Gardner, I. (2018, July 31). Olympic gold medalist Nastia Liukin on her empowerment app Grander \& the importance of inspiring women. Boston Common. Retrieved from https://bostoncommon-magazine.com/nastia-liukin-on-empowering-women

Geurin, A.N. (2017). Elite female athletes' perceptions of new media use relating to their careers: A qualitative analysis. Journal of Sport Management, 31(4), 345-359. https://doi.org/10.1123/jsm.2016-0157

Geurin-Eagleman, A.N., \& Burch, L.M. (2016). Communicating via photographs: A gendered analysis of Olympic athletes' visual self-presentation on Instagram. Sport Management Review, 19(2), 133-145. doi:10.1016/j.smr.2015.03.002

Greer, J.D., Hardin, M., \& Homan, C. (2009). "Naturally" less exciting? Visual production of men's and women's track and field coverage during the 2004 Olympics. Journal of Broadcasting \& Electronic Media, 53(2), 173-189.

Hedenborg, S. (2013). The Olympic Games in London 2012 from a Swedish media perspective. The International Journal of the History of Sport, 30(7), 789-804. http://dx.doi.org/10.1080/09523367.2013.773889

Higgs, C.T., \& Weiller, K.H. (1994). Gender bias and the 1992 Summer Olympic Games: An analysis of television coverage. Journal of Sport and Social Issues, 18(3), 234-246.

Hill, C. (2018, October 15). USA Gymnastics interim president faces scrutiny from Simone Biles, Aly Raisman. Indianapolis Star. Retrieved from https://www.indystar.com/story/news/2018/10/15/usa-gymnastics-under-fire-bilesraisman-mary-bono-hire/1652340002/

Kane, M.J. (1995). Resistance/Transformation of the oppositional binary: Exposing sport as a continuum. Journal of Sport and Social Issues, 19(2), 191-218. https://doi.org/10.1177/019372395019002006

Kane, M.J., \& Maxwell, H.D. (2011). Expanding the boundaries of sport media research: Using critical theory to explore consumer responses to representations of women's sports. Journal of Sport Management, 25, 202-216.

King, C. (2007). Media portrayals of male and female athletes: A text and picture analysis of British national newspaper coverage of the Olympic Games since 1948. International Review for the Sociology of Sport, 42(2), 187-199.

Lai, K.K.R., \& Lee, J.C. (2016, August 24). The countries where women won more medals than men in Rio. The New York Times. Retrieved from 
https://www.nytimes.com/interactive/2016/08/24/sports/olympics/countries-wherewomen-won-more-medals-than-men-in-rio.html

Lebel, K., \& Danylchuk, K. (2012). How tweet it is: A gendered analysis of professional tennis players' self presentation on Twitter. International Journal of Sport Communication, 5, 461-480. doi:10.1123/ijsc.5.4.461

MacArthur, P.J., Angelini, J.R., Smith, L.R., \& Billings, A.C. (2017). The Canadian state of mind: Coverage of men and women athletes in the Canadian Broadcasting Corporation's prime time broadcast of the 2014 Sochi Winter Olympic Games. Journal of Broadcasting \& Electronic Media, 61(2), 410-429. https://doi.org/10.1080/08838151.2017.1309412

Messner, M., Duncan, M.C, \& Jensen, K. (1993). Separating the men from the girls: The gendered language of televised sport. Gender and Society, 7, 121-137.

Myre, G. (2016, August 21). U.S. women are the biggest winners at the Rio Olympics. NPR. Retrieved from https://www.npr.org/sections/thetorch/2016/08/21/490818961/u-swomen-are-the-biggest-winners-in-rio-olympics

Packer, C., Geh, D.J., Goulden, O.W., Jordan, A.M., Withers, G.K., Wagstaff, A.J., Bellwood, R.A., Binmore, C.L., \& Webster, C.L. (2014). No lasting legacy: No change in reporting of women's sports in the British print media with the London 2012 Olympics and Paralympics. Journal of Public Health, 37(1), 50-56. doi:10.1093/pubmed/fdu018

Sandomir, R. (2014, May 7). NBC extends Olympic deal into unknown. The New York Times. Retrieved from https://www.nytimes.com/2014/05/08/sports/olympics/nbc-extendsolympic-tv-deal-through-2032.html

Smartt, N. (2017, December 20). Sexual harassment in the workplace in a \#MeToo world. Forbes. Retrieved from https://www.forbes.com/sites/forbeshumanresourcescouncil/2017/12/20/sexualharassment-in-the-workplace-in-a-metoo-world/\#79ae25f55a42

Smith, M.M., \& Wrynn, A.M. (2010). Women in the 2010 Winter Olympic and Paralympic Games: An Analysis of Participation, Leadership, and Media Opportunities, A Women's Sports Foundation Research Report. East Meadow, NY: Women's Sports Foundation. Retrieved from https://www.womenssportsfoundation.org/wpcontent/uploads/2016/08/2010_olympic report.pdf

Taylor, L. (2018, February 12). Female athletes race towards gender equality at Winter Olympics. Reuters. Retrieved from https://www.reuters.com/article/us-olympics-2018women/female-athletes-race-towards-gender-equality-at-winter-olympicsidUSKBN1FW1M7 
Villalon, C., \& Weiller-Abels, K. (2018). NBC's televised media portrayal of female athletes in the 2016 Rio Summer Olympic Games: A critical feminist view. Sport in Society, 21(8), 1137-1157. doi:10.1080/17430437.2018.1442206

Xu, Q., Billings, A., \& Fan, M. (2018). When women fail to "hold up more than half the sky": Gendered frames of CCTV's coverage of gymnastics at the 2016 Summer Olympics. Communication \& Sport, 6(2), 154-174. doi: 10.1177/2167479517695542

Zurn, L., Lopiano, D., \& Snyder, M. (2006). Women in the 2006 Olympic and Paralympic Winter Games: An analysis of participation, leadership and media coverage. East Meadow, NY: Women's Sports Foundation. Retrieved from https://www.womenssportsfoundation.org/wpcontent/uploads/2016/08/2006 olympic_report.pdf 